\title{
Factors Affecting Liquidity in Indonesian Sub Sector Metal Industries
}

\author{
Hantono Hantono* | Teng Sauh Hwee \\ Faculty of Economics, Universitas Prima Indonesia, Indonesia
}

\begin{abstract}
The purpose of this research is to verify and analyze the factors that affect the liquidity in sub-sector metal industries listed on Indonesia Stock Exchange (IDX). We purposively use 10 firms out of 16 firms because of these 16 firms does not meet our criteria. This paper comprehensively investigates step-bystep of statistical analysis from classical assumption testing such as normality, heteroscedasticity, autocorrelation, and multicollinearity and then continued by testing model and variables using t-test and F-test. our testing result shows that we do not have problem of classical assumptions. We also find that net working capital turnover, account receivable turnover and inventory turnover significantly affect firm liquidity.
\end{abstract}

Keywords: net working capital turnover, account receivable turnover, inventory turnover, liquidity.

\section{Introduction}

Economic development cannot be separated from metal sector. This is because the metal is one of the sectors that has an important role in economic activities. For example, ceramic, glass and porcelain manufaturers have good prospects in the future due to the development of property industry in Indonesia. This paper aims to investigate what factors affecting liquidity in the sub metal industries. This research is related to the study that has been done before by Sugiono and Christiawan (2013) finding that working turnover affects the liquidity of the firms listed in IDX. Meanwhile, firm size, growth opportunity, and working capital turnover do not have significant influence on liquidity. Maulana and Widhiannigrum (2016) on the other hand shows that a variable turnover of receivables and working capital turnover do not affect the current ratio. Syahputra (2009) shows that the cash turnover has a significant influence towards the current ratio. However, receivable turnover and inventory turnover do not have a significant impact on current ratio. Based on these prior studies, we highlight here several variables predictably affects liquidity.

The first factor in our analysis is net working capital. It is the difference between current assets and current liabilities. The net working capital approximately shows the potential of a company's cash reserves (Wahyudiono, 2014). Working capital turnover is the ratio between net sales and working capital. This ratio shows how frequent the funds embedded in working capital in one period or the amount of sales that can be achieved by any rupiah in the working capital (Munawir, 2014). Working capital turnover is the ratio to measure or review the effectiveness of company's working capital throughout a certain period which means how much working capital is being used in a certain period. To measure this ratio, the sales are compared with the average working capital (Kasmir, 2008).

Inventory turnover is a ratio used to measure how frequent the funds embedded in inventory will rotate in one period (Hery, 2015). Company with higher inventory turnover has more efficiency in sales performance. However, if it's too high it will give negative impact to the company. Thus it is necessary to determine the balance (Sartono, 2014). This ratio shows how frequent the inventory changes in a year. The higher the inventory turnover, the faster the company will turn back the embedded funds in

${ }^{*}$ Corresponding author. Email: hantono 78@yahoo.com 
the inventory into cash (Sugiono, 2016). Indicators used to calculate the inventory turnover is (Brigham and Houston, 2014):

Receivable turnover is a ratio used to measure the frequency of funds embedded in trade receivables that will rotate in one period or duration (in days) of the average collection of accounts receivable. This ratio shows the quality of the receivables and the management ability to collect the company's receivable account. In other words, this ratio illustrates how quick the account receivable is being collected into cash (Hery, 2016). The decrease in this ratio according to Murhadi (2015), can be caused by several things such as decrease in sales and increase in account receivable; decrease in account receivable and sales in large amount; increase in account receivable and sales in large amount; decrease in sales with the same account receivable; and increase in account receivable while the sales are the same.

Account receivable turnover can be calculated by dividing the net credit sales with the average account receivable or the value of final accounts. High account receivable turnover is better because the working capital invested in the account receivable will be lower (Jumingan, 2014). Current ratio is the ability of company's current asset to meet short term liabilities with company's current assets (Sumarsan, 2011). This ratio is used to measure company's ability to pay short term obligations or debt when billed as a whole (Kasmir, 2012).

Based on the issues and some theoretical studies that have been discussed, this paper is quite important because papers investigating liquidity in sub metal industries is relatively rare compared to other industries. We then divide this paper into several parts. First section is introduction. Next section is methodology. Third section is result. The last section concludes.

\section{Method}

This study uses the secondary data based on company's financial statements in sub-sector metal companies listed on Indonesia Stock Exchange (IDX) in the 2011-2015 period that can be accessed through www.idx.co.id. From the observation we have done in the website, we obtain 10 metal firms so that we have 50 observations in total. Independent Variable used in this research is working capital turnover, inventory turnover, and receivable turnover. Working capital turnover $\left(\mathrm{X}_{1}\right)$ is the ratio between net sales and working capital. This ratio shows how frequent the fund embedded in working capital are turnover in one period or the amount of sales that can be achieved bay any rupiah working capital (Munawir, 2014). Inventory turnover $\left(\mathrm{X}_{2}\right)$ measures how frequent is the fund embedded in the inventory will rotate in one period (Hery, 2015). Receivable turnover $\left(\mathrm{X}_{3}\right)$ measures how frequent the fund embedded in account receivable will rotate in one period or duration (in days) of the average collection of accounts receivable. This ratio shows the quality of account receivable activities. In other words, this ratio illustrates how quickly account receivable is successfully turns back into cash (Brigham and Houston, 2014). For dependent variable, we use the company's current ratio defined as current assets divided by current liabilities. The conceptual framework could be seen in the Figure 1 .

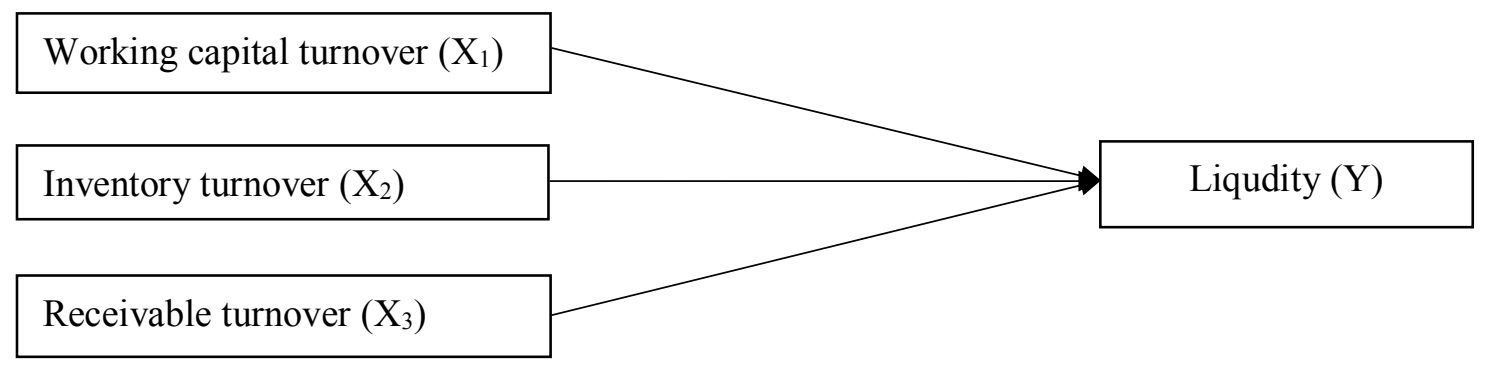

Figure 1. Conceptual framework

We do not hypothesize one-by-one regarding the impact of each variable. However, we predict that all independent variables significantly affect liquidity. This research uses multiple linear regression analysis after the classic assumption test was done. All testing is carried out using statistical package for social sciences (SPSS) software. 


\section{Result and Discussion}

Based on the data from financial statements in the 2011-2015, it can be seen the minimum, maximum, mean and standard deviation value of each variable in the Table 1.

Table 1. Descriptive Statistics

\begin{tabular}{llrrrr}
\hline & $\mathrm{N}$ & Minimum & Maximum & \multicolumn{1}{c}{ Mean } & Std. Deviation \\
\hline Working capital turnover & 50 & -2.22 & 717.86 & 28.9328 & 115.39932 \\
Inventory turnover & 50 & 0.07 & 94.93 & 9.7843 & 17.57956 \\
Account receivable turnover & 50 & 0.51 & 133.57 & 8.6068 & 18.40169 \\
Current ratio & 50 & 0.90 & 464.98 & 17.6156 & 73.25814 \\
\hline
\end{tabular}

Based on the results of the calculations in Table 1, average working capital turnover shows irregularities due to deviation standard value is higher than mean value. This result indicates the current ratio is bad because the standard deviation reflecting the variable data is high as it is greater than average value. The same results are also applicable for the other variables such as inventory turnover and account receivable turnover.

Because the analysis tool used is multiple linear regression analysis and data used in this research is secondary data, it means to meet all the conditions the temporary result need to be tested on some classical assumptions were used normality test, multicollinearity, heteroscedasticity and autocorrelation test. Result of the test indicate that the data in this research is not experiencing problems with classical assumption tests. The test result data normality using graph analysis can be seen at Figure 2 below:

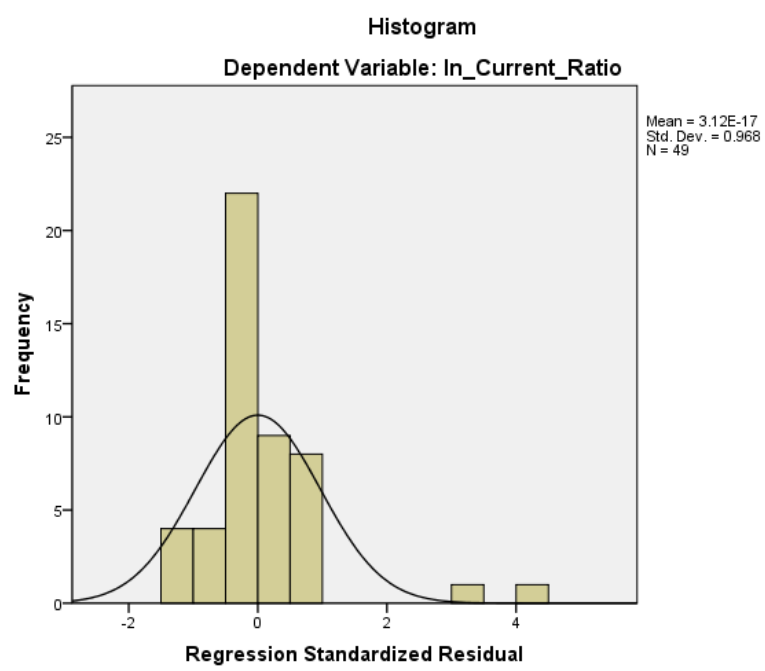

Figure 2. Histogram for data normality test

Figure 2 shows that the curves tend to be symmetrical (U), which means the data distribution is normal. Normal probability plot result can be seen in the Figure 3. In Figure 3, the points spread around the normal line and follow the direction of the diagonal line and it shows that the data is normally distributed, that means the regression model is normal. Kolmogorov Smirnov tests appeared in Table 2 also show a significant value $0.251>0.05$ thus it can be concluded that the data is distributed normally. Multicollinearity testing results in this research at Table 3. Table 3 shows tolerance value of working capital turnover, inventory turnover, and receivable turnover are above 0.10 and VIF value of all variable is under 10. It means no correlations between variables. 


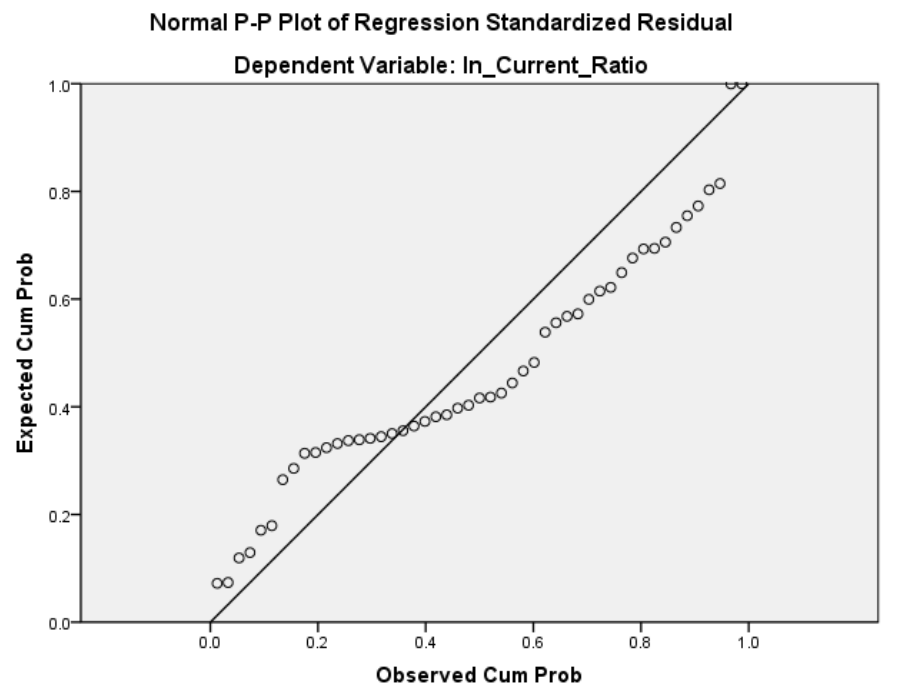

Figure 3. Normal probability plots for normality testing

Table 2. Kolmogorov- Smirnov test

\begin{tabular}{|c|c|c|}
\hline & & Unstandardized Residual \\
\hline $\mathrm{N}$ & & 50 \\
\hline Normal Parameters ${ }^{\text {a.b }}$ & Mean & 0.000 \\
\hline & Std. Deviation & 0.954 \\
\hline Most Extreme Differences & Absolute & 0.145 \\
\hline & Positive & 0.145 \\
\hline & Negative & -0.145 \\
\hline Kolmogorov-Smirnov Z & & 1.017 \\
\hline Asymp. Sig. (2-tailed) & & 0.252 \\
\hline
\end{tabular}

From the scatterplot graph in Figure 4, it can be seen that the points are randomly spread both above and below zero on the $\mathrm{Y}$ axis. It can be concluded that there is an absence of heteroscedasticity which make the model is feasible to use research. Next, the result of auto-correlation test using Durbin Watson are as follows. The table above shows the results of data processing which obtains 2.174 statistical value of Durbin-Watson (DW). The Durbin-Watson test table on $\alpha=0,05$ for 3 independent variable and total samples are 50 obtained lower value bound $(\mathrm{dL})=1.4206$ and upper value bound $(\mathrm{dU})=1.6739 . \mathrm{DW}$ value $=2.604$ which is more than du and smaller than $(4-\mathrm{du}=4-1.6739=2.3261)$ is $1.4206<2.174<2.3261$ so DW value 2,174 is greater than the upper limit (dU) and less than $(4-$ dU) so it can be concluded that there is no autocorrelation.

Table 3. Multicollinearity Test

\begin{tabular}{llrc}
\hline \multirow{2}{*}{ Model } & & \multicolumn{2}{c}{ Collinearity Statistics } \\
\cline { 3 - 4 } & & Tolerance & \multicolumn{1}{c}{ VIF } \\
\hline \multirow{2}{*}{1} & Working capital turnover & 0.764 & 1.309 \\
& Inventory turnover & 0.769 & 1.300 \\
& Account receivable turnover & 0.974 & 1.027 \\
\hline
\end{tabular}

a. Dependent Variable: Current Ratio 


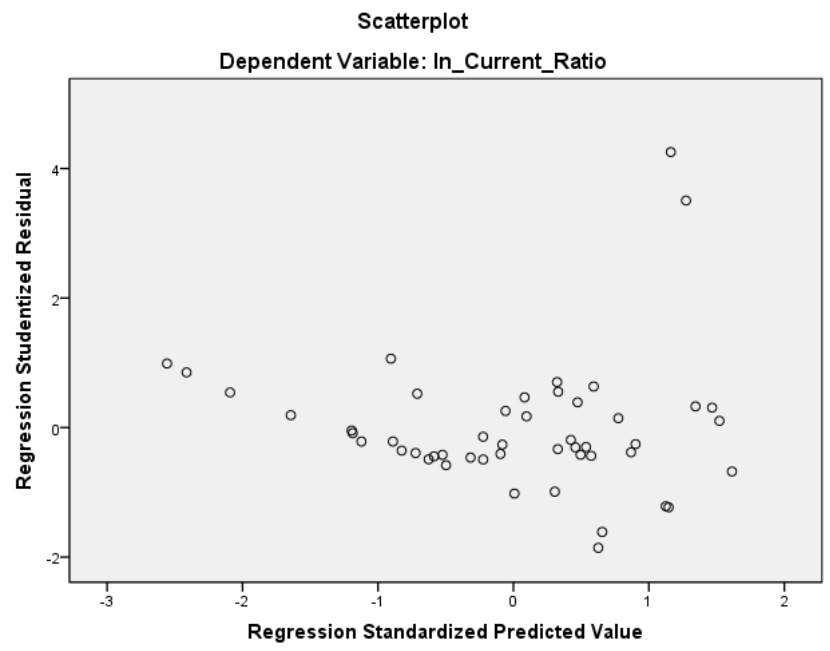

Figure 4. Scatterplot for heteroscedasticity test

The result of $F$ Test in table 5 shows the significance of the test. $F_{\text {count }}$ is 10.023 . at degrees of freedom $1\left(\mathrm{df}_{1}\right)=\mathrm{k}-1=3-1=2$, and degrees of freedom $2\left(\mathrm{df}_{2}\right)=\mathrm{n}-\mathrm{k}=50-3=47$, where $\mathrm{n}=$ total samples, $\mathrm{k}=$ total variabel, $\mathrm{F}_{\text {Table }}$ at significant 0,05 is 2,80 thus $\mathrm{F}_{\text {count }}=10.023>\mathrm{F}_{\text {table }}=2.80$ with significance level 0,000. Because the probability significance is much greater than sig. $0.000>0,05$, then $\mathrm{Ha}$ is denied which means working capital turnover, account receivable turnover, and inventory turnover altogether affect the current ratio of sub-sector metal industries listed in Indonesia Stock Exchange during the period 2011-2015.

Table 4. Autocorrelation Test

\begin{tabular}{cccccc}
\hline Model & $\mathrm{R}$ & $\mathrm{R}$ Square & $\begin{array}{c}\text { Adjusted R } \\
\text { Square }\end{array}$ & $\begin{array}{c}\text { Std. Error of } \\
\text { the Estimate }\end{array}$ & $\begin{array}{c}\text { Durbin } \\
\text { Watson }\end{array}$ \\
\hline 1 & 0.533 & 0.401 & 0.361 & 0.98615 & 2.174 \\
\hline
\end{tabular}

Table 5. Simultaneous Test (F- Test)

\begin{tabular}{|c|c|c|c|c|c|}
\hline & & noval & & & \\
\hline Model & Sum of Square & $\mathrm{df}$ & Mean Square & $\mathrm{F}$ & Sig \\
\hline Regression & 29.242 & 3 & 9.747 & 10.023 & 0.000 \\
\hline Residual & 43.762 & 45 & 0.972 & & \\
\hline Total & 73.004 & 48 & & & \\
\hline
\end{tabular}

Next, because all the classical assumption tests show no problem, we go to the t-test. This test will show to us whether working capital turnover, inventory turnover, and account receivable turnover significantly affect liquidity. The result of t-test is shown in Table 6.

Table 6. T-Test result

\begin{tabular}{|c|c|c|c|c|c|}
\hline \multirow[t]{2}{*}{ Variables } & \multicolumn{2}{|c|}{$\begin{array}{l}\text { Unstandardized } \\
\text { Coefficients }\end{array}$} & \multirow{2}{*}{$\begin{array}{c}\begin{array}{c}\text { Standardized } \\
\text { Coefficients }\end{array} \\
\text { Beta }\end{array}$} & \multirow[t]{2}{*}{$\mathrm{t}$} & \multirow[t]{2}{*}{ Sig } \\
\hline & Beta & Std. Error & & & \\
\hline Constant & 1.647 & 0.332 & & 4.966 & 0.000 \\
\hline Working capital turnover & -0.466 & 0.098 & -0.631 & -4.781 & 0.000 \\
\hline Inventory turnover & 0.398 & 0.150 & 0.350 & 2.662 & 0.011 \\
\hline Account receivable turnover & -0.319 & 0.147 & -0.254 & -.0254 & 0.035 \\
\hline
\end{tabular}


The results of partial test (t-test) variable of working capital turnover shows the value of $t$ count $<$ $\mathrm{t}$ table $(-4.781<2.011)$ and significance value which is under 0.05 meaning that $\mathrm{H}_{0}$ can be accepted and $\mathrm{H}_{1}$ is rejected where there is no significance influence between working capital turnover on current ratio on sub-sector metal industries. This result support Sugiono and Christiawan (2013) research that claim working capital turnover affects the liquidity. On the contrary, this research support Maulana and Widhiannigrum's (2016) research, which says that working capital turnover does not affect the current ratio.

The results of partial test (t-test) variable inventory turnover shows the value $t$ count $<\mathrm{t}$ table and significance under 0.05 meaning that $\mathrm{H}_{0}$ is accepted and $\mathrm{H}_{1}$ is rejected. Therefore, there is no significance influence between inventory turnover on current ratio on sub-sector metal industries. This result supports Syahputra's (2009) research. Which says that inventory turnover does not affect the current ratio.

The results of partial test (t-test) variable account receivable turnover shows the value of $t$ count $<$ $\mathrm{t}$ table and significance under 0.05 meaning that there is significance influence of account receivable turnover towards the current ratio on sub-sector metal industries. This result consistent to Syahputra (2009) who find that account receivable turnover does not affect the current ratio.

The multiple linear regression equation is:

\section{Current Ratio $=1.647-0.466$ Ln (Working Capital Turnover $)+0.398$ Ln (Inventory Turnover $)-0.319$ Ln (Account Receivable Turnover)}

From the multiple linear regression equation, the constants is 1.647 which means if all variable independent considered constant, the value of current ratio will be 1.647. Variable working capital turnover has a regression coefficient $-0,466$ thus if working capital turnover increase one coefficient, current ratio will drop - 0.466 times. Variable inventory turnover has a regression coefficient 0.398 it means that if inventory turnover increase one coefficient, current ratio will increase 0.398 times. Variable account receivable turnover has a regression coefficient $-0,319$ it means that if account receivable turnover increase by one coefficient, current ratio will drop -0.319 times.

Coefficient determination test used to measure how much influence the working capital turnover, inventory turnover and accounts receivable turnover variable. The result can be seen in Table 7 .

Table 7. Coefficient Determination Test

\begin{tabular}{cccccc}
\hline Model & $\mathrm{R}$ & $\mathrm{R}$ Square & $\begin{array}{c}\text { Adjusted R } \\
\text { Square }\end{array}$ & $\begin{array}{c}\text { Std. Error of } \\
\text { the Estimate }\end{array}$ & $\begin{array}{c}\text { Durbin } \\
\text { Watson }\end{array}$ \\
\hline 1 & $.633^{\mathrm{a}}$ & .401 & .361 & .98615 & 2.174 \\
\hline
\end{tabular}

In Table 7 shows that coefficient determination (adjusted R square) is $36,1 \%$. It means the effect of current ratio $36,1 \%$ can be explained by the variation of the three independent variables, $63,9 \%$ explained by other variable not used in this research.

\section{Conclusion}

This paper investigates the impact of working capital turnover, inventory turnover and account receivable turnover affects the current ratio on sub-sector metal industries in Indonesia Stock Exchange period 2011-2015. We find significant effects of all variable in this research on current ratio. Our result are consistent with several prior studies such as Sugiono and Christiawan (2013) research that claim working capital turnover affects the liquidity, Maulana and Widhiannigrum's (2016) research which says that working capital turnover does not affect the current ratio, and Syahputra (2009) who find that account receivable turnover affects the current ratio.

\section{References}

Brigham, E.F. and Houston, J.F. (2014), Dasar-Dasar Manajemen Keuangan, Edisi 11,., Penerbit Salemba Empat, Jakarta.

Hery, H. (2015), Analisis Laporan Keuangan, Penerbit CAPS, Yogyakarta. 
Hery, H. (2016), Financial Ratio for Business, Penerbit PT.Grasindo.

Jumingan, J. (2014), Analisis Laporan Keuangan, Penerbit PT.Bumi Aksara, Jakarta.

Kasmir, K. (2008), Analisa Laporan Keuangan, Penerbit PT.Rajagrafindo Persada, Jakarta.

Kasmir, K. (2012), Analisis Laporan Keuangan, Penerbit Kencana, Jakarta.

Maulana, R.A. and Widhiannigrum, P. (2016), "The change of account receivable, equity, and leverage on Current ratio in mining firms", Journal of Accounting and Business Education, Vol. 1 No. 1.

Munawir, S. (2014), Analisa Laporan Keuangan, Edisi Keem., Penerbit Liberty, Yogyakarta.

Murhadi, W. (2015), Analisis Laporan Keuangan Proyeksi Dan Valuasi Saham, Penerbit Salemba Empat, Jakarta.

Sartono, A. (2014), Manajemen Keuangan Teori Dan Aplikasi, Penerbit BPFE UGM, Yogyakarta.

Sugiono, A. (2016), Panduan Praktis Dasar Analisa Laporan Keuangan, Penerbit PT.Grasindo, Jakarta.

Sugiono, L.P. and Christiawan, Y.J. (2013), “Analisa Faktor yang Mempengaruhi Likuiditas Pada Industri Ritel yang Terdaftar Pada Bursa Efek IndonesiaTahun 2007-2012”, Business Accounting Review, Vol. Vol. 1 No. No. 2.

Sumarsan, T. (2011), Sistem Pengendalian Manajemen, Penerbit Indeks, Jakarta.

Sunyoto, D. (2013), Analisis Laporan Keuangan Untuk Bisnis, Penerbit CAPS, Yogyakarta.

Syahputra, I. (2009), "Pengaruh Perputaran Modal Kerja, Tingkat Pertumbuhan Penjualan Terhadap Current Ratio Pada Perusahaan Aneka Industri Yang Terdaftar Di Bursa Efek Indonesia Periode 2010-2013”, Jurnal Akuntansi UMRAH.

Wahyudiono, B. (2014), Mudah Membaca Laporan Keuangan, Penerbit Raih Asa Sukses (Penebar Swadaya Grup). 